\title{
Introduction: Origins and Settlement of the Indigenous Populations of the Aleutian Archipelago
}

Author(s): Dixie West, Dennis O'Rourke, and Michael H. Crawford

Source: Human Biology, 82(5/6):481-486.

Published By: Wayne State University Press

URL: http://www.bioone.org/doi/full/10.3378/027.082.0501

BioOne (www.bioone.org) is a nonprofit, online aggregation of core research in the biological, ecological, and environmental sciences. BioOne provides a sustainable online platform for over 170 journals and books published by nonprofit societies, associations, museums, institutions, and presses.

Your use of this PDF, the BioOne Web site, and all posted and associated content indicates your acceptance of BioOne's Terms of Use, available at www.bioone.org/ page/terms of use.

Usage of BioOne content is strictly limited to personal, educational, and noncommercial use. Commercial inquiries or rights and permissions requests should be directed to the individual publisher as copyright holder. 


\title{
Introduction: Origins and Settlement of the Indigenous Populations of the Aleutian Archipelago
}

\author{
DIXIE WEST, ${ }^{1}$ DENNIS O'ROURKE, ${ }^{2}$ AND MICHAEL H. CRAWFORD ${ }^{3}$
}

The series of papers in this special issue of Human Biology use an interdisciplinary approach to address regional questions and to integrate disparate Aleutian data into a broad, synthetic effort. The contributors leverage decades of data on Aleut origins, biogeography, and behavior through integration of molecular analyses, linguistics, archaeology, and ethnography. This research explores the origin and colonization of the Aleutian archipelago, communication and the extent of prehistoric cultural exchange among Aleut subgroups, ethnographic information as applied to human biological variation, metric and genetic variation among Aleut groups, and prehistoric dietary reconstruction.

The Aleutian archipelago, composed of eastern, central, and western islands, extends 1,800 km between the North American and Asian continents and divides the northern Pacific Ocean from the Bering Sea. Volcanic in origin and formed during the early Tertiary, the archipelago is composed of more than 200 islands divided into six groups, separated by ocean passes. The climate is maritime and is characterized by foggy and cloudy weather, frequent rain and winds, and often cold but not severe annual temperatures. The Aleutians form the southern boundary for the most biologically and commercially important region of the Pacific - the Bering Sea. Until recently, this area was a rich ecotone that supported abundant populations of large marine mammals, ocean fisheries, thick kelp forests, complex near-shore ecosystems and intertidal zones, spawning streams, and a highly diverse avian fauna pivotal to the adaptations and survival of the human groups who, in the past, peopled the islands of the archipelago. However, the Aleutians, once considered one of the richest island ecosystems in the world, have been undergoing considerable biotic turnover (Estes and Duggins 1995). Population densities of marine mammals and some economical fish have dramatically declined, and the once thick kelp forests have decreased (Committee on the Alaska Groundfish Fishery and Steller Sea Lions 2003; Trites et al. 1999). In contrast, Aleutian waters have witnessed increases in sea urchin, pollack, and

\footnotetext{
${ }^{1}$ Biodiversity Institute and Natural History Museum, University of Kansas, Lawrence, KS 66045.

${ }^{2}$ Department of Anthropology, University of Utah, Salt Lake City, UT 84112. KS 66045

${ }^{3}$ Laboratory of Biological Anthropology, Department of Anthropology, University of Kansas, Lawrence,
}

Human Biology, October-December 2010, v. 82, nos. 5-6, pp. 481-486.

Copyright $\odot 2010$ Wayne State University Press, Detroit, Michigan 48201-1309

KEY WORDS: ALEUTIAN ISLANDS, INDIGENOUS PEOPLES, COLONIZATION, CONTACT, BIOLOGY. 
shark populations, species that were historically uncommon in this ecosystem (Estes et al. 1998; Springer 1999). This biotic restructuring has occurred over a short time period and carries socioeconomic consequences and lessons for local inhabitants-and the world community, especially if rapid global warming is the cause (Estes et al. 1998).

The Aleutian Islands define the southern margin of Beringia, across which much of the early peopling of the Americas occurred, and present a 9,000-year record of human occupation in the east and a record of more than 3,000 years in the west. Current research suggests that these prehistoric human inhabitants had minimal interactions with populations outside the archipelago, with any new interactions commencing from the Alaska Peninsula. These remote islands preserve the critical cultural and biological information of peoples who settled, adapted, and thrived in a subarctic maritime world.

The historical record of the Aleut peoples, like many other Native Americans, is one of exploitation and decimation resulting from disease and warfare. During the 18th century, the arrival from Russia of sea otter hunters, followed by Russian Orthodox missionaries, had a drastic effect on Aleutian populations and their hunter-gatherer culture, economy, and maritime environment (Tikhmenev 1978). Upon contact, the native population declined rapidly; by 1831 only 16 islands were inhabited by an estimated 2,000 natives (Sekora 1973). This initial historical period has provided the richest reservoir of ethnographic data (Berkh 1974; Black 1984; Lantis 1970; Liapunova 1996; Veniaminov 1984), which largely focus on Aleuts living on the eastern islands. A second devastating blow to Aleut culture occurred in 1943, when the Imperial Japanese Navy bombed Dutch Harbor in the eastern Aleutians and captured Kiska and Attu islands to the west. Naval weather observers on Kiska and Attuans were relocated to prisoner-of-war camps in Hokkaido, Japan, where less than half of them survived. The American military relocated Aleuts living in nine villages on six islands to evacuation camps in southeast Alaska for 3 years, where over 10\% died. In the best interests of the United States, American troops burned some Aleut villages rather than allow Japanese occupation (Kohlhoff 1995). Currently, most islands in the archipelago are uninhabited.

Aleutian research is disjunctive at best. Scientific study of the archipelago began shortly after Russia sold the Aleutian Islands and Alaska to the United States in 1867. Pinart $(1873,1875)$ and Dall $(1877,1899)$ initiated the first archaeological inquiries, followed by Jochelson (1925, 1933) and Hrdlička (1945). Unfortunately, the results of these early collecting expeditions are of minimal use in understanding prehistoric cultural and environmental dynamics because the artifacts, themselves selectively recovered, often lack clear stratigraphic or geochronological contexts. Also, because of their relative isolation and inaccessibility, the western Aleutians were not thoroughly investigated until the past two decades and the central Aleutians remain comparatively unstudied. Therefore research is neither comprehensive nor synthetic across the Aleutian chain. Third, a precise chronology is essential to testing hypotheses concerning correlations and causes 
of events in past natural and human systems. However, North Pacific shell, fishbone, and other materials in the marine food chain have radiocarbon ages that are 600-1,000 years older than those for coeval terrestrial material (Kuzmin et al. 2001; Southon et al. 1990; Stuiver et al. 1986) because of the strong upwelling of aged (radiocarbon-depleted) subsurface waters into the North Pacific mixed layer. This offset or reservoir age must be taken into account when evaluating radiocarbon dates on marine materials and terrestrial consumers of marine diets in order to avoid major errors in interpretation. Along with required corrections being as high as 600-1,000 years (Stuiver et al. 1986), oceanographic variability along the Aleutian chain suggests that significant spatial variations must be considered (Favorite et al. 1976). Finally, much prehistoric Aleutian data are stored at government agencies in the form of comparatively inaccessible, unpublished, and undigitized reports. Although problematic, these issues are not insurmountable.

By integrating ethnographic, archaeological, and biological data in the Bering Sea region, the contributors to this special issue of Human Biology pose and address six fundamental demographic and evolutionary questions.

1. Where did the indigenous Aleut populations originate? Several of the articles in this special issue address this question. Raff and colleagues examine migration patterns from the Alaska Peninsula based on ancient mtDNA sequences. Crawford and co-workers examine the subsequent molecular variation in contemporary Aleutian populations and find that Aleuts cluster closest to the Siberian Chukchi and Yupik Eskimo populations. Berge describes linguistic affinities between Siberian and Aleut groups.

2. When did the Aleut founding populations settle the archipelago? This question is primarily addressed through archaeological excavations and radiocarbon dating in the contribution by Davis and Knecht on the settlement of the eastern islands. Hatfield reviews the chronology and material culture associated with prehistoric Aleut movements. Veltre and Smith provide a historical overview of the archaeological data throughout the Aleutian Islands.

3. Is there evidence of prehistoric contact of Aleuts with neighboring populations? Berge examines linguistic evidence of possible contact of Aleuts with Eskimo and Na-Dene-speaking groups. Justice and colleagues compare the morphological variation in Eskimo populations of St. Lawrence Island with Aleuts of St. Paul Island in the Pribilofs. Crawford and colleagues compare mtDNA sequences and Y-chromosome markers of Aleuts with those of Siberian and other Alaskan populations.

4. Did replacement of the Paleo-Aleuts by Neo-Aleuts, as originally hypothesized by Hrdlička, take place about 1,000 years ago? Raff and colleagues, using recent mtDNA evidence from Alaska Peninsula archaeological sites, examine potential sources of eastern migration. Ousley and Jones analyze craniometric data to test previous hypotheses about Aleut origins and evolution; they determine that environment may have played a key role in morphologic change over time. In her contribution to this special issue, Coltrain examines stable carbon and 


\section{4 / WEST ET AL.}

nitrogen isotopes from bone collagen to reconstruct changing subsistence strategies. Davis and Knecht review the archaeological sequences in the eastern islands for possible discontinuity.

5. What were the demographic and genetic consequences of European contact with Aleutian populations? Rubicz and co-workers analyze the genetic architecture of an aggregated island population off the coast of Kamchatka, created by Russian colonists for supplying their expeditions and harvesting furs from the breeding sites on Bering Island. Reedy-Maschner poses the question of what happened to the Aleut males and addresses it through the examination of demographic and historical documents. Graf and colleagues determine that Aleut surname origin, distribution, and association with Y-chromosome haplogroups is culturally rather than biologically driven. Crawford and co-workers, through the analyses of Y-chromosome markers and mtDNA sequences, demonstrate that the gene flow from European populations into the Aleut gene pool was asymmetric and that only $15 \%$ of the $\mathrm{Y}$ chromosomes were of indigenous origins. Rey and colleagues examine the variation of $H L A$ haplotypes in Aleuts of Bering Island and identify the nature of the gene flow.

6. Is there evidence for linguistic, genetic, material culture, and morphological differentiation along the Aleutian archipelago following the settlement of the islands? This question is addressed by Crawford and colleagues, based on mtDNA variation; Berge, using linguistic data; and Hatfield, examining material culture.

By virtue of their geography and history, the Aleutian Islands provide a model system for studying human adaptations and interactions from 9,000 years ago to the present. Composing the southern boundary of Beringia and the westernmost area of North America, the Aleutian archipelago and its indigenous population provide critical information about the peopling of the New World. In addition, the archipelago holds key information about the reciprocal effects of humans and their environments through deep time. Cooperation among academic disciplines, as in the papers that follow, throws new light on this culturally rich and economically important area of the world.

Received 8 June 2010; accepted for publication 29 June 2010.

\section{Literature Cited}

Berkh, V. N. 1974 [1823]. A Chronological History of the Discovery of the Aleutian Islands or the Exploits of Russian Merchants, D. Krenov, trans. Kingston, Canada: Limestone Press.

Black, L. T. 1984. Atka: An Ethnohistory of the Western Aleutians. Kingston, Canada: Limestone Press.

Committee on the Alaska Groundfish Fishery and Steller Sea Lions. 2003. Decline of the Steller Sea Lion in Alaskan Waters. Washington, DC: National Academies Press.

Dall, W. H. 1877. On succession in the shell-heaps of the Aleutian Islands. In Contributions to North American Ethnology, v. 1, pt. 1, Tribes of the Extreme Northwest, by W. H. Dall. Washington, DC: U.S. Government Printing Office. 
Dall, W. H. 1899. On the Remains of Later Prehistoric Man, Obtained from Caves in the Catherina Archipelago, Alaska Territory, and Especially from the Caves of the Aleutian Islands. Smithsonian Contributions to Knowledge 318. Washington, DC: Smithsonian Institution.

Estes, J., and D. Duggins. 1995. Sea otters and kelp forests in Alaska: Generality and variation in a community ecological paradigm. Ecol. Monogr. 65:75-100.

Estes, J., M. Tinker, T. Williams et al. 1998. Killer whale predation on sea otters linking coastal with oceanic ecosystems. Science 282:473-476.

Favorite, F., A. J. Dodimead, and K. Nasu. 1976. Oceanography of the Subarctic Pacific Region, 1960-71. International North Pacific Fisheries Commission Bulletin 33. Vancouver, Canada: International North Pacific Fisheries Commission.

Hrdlička, A. 1945. The Aleutian and Commander Islands and Their Inhabitants. Philadelphia: Wistar Institute of Anatomy and Biology.

Jochelson, V. I. 1925. Archaeological Investigations in the Aleutian Islands. Carnegie Institution of Washington Publication 367. Washington, DC: Carnegie Institution of Washington.

Jochelson, V. I. 1933. History, Ethnology, and Anthropology of the Aleut. Carnegie Institution of Washington Publication 432. Washington, DC: Carnegie Institution of Washington (reprinted in 1968 by Anthropological Publications, Oosterhout, The Netherlands).

Kohlhoff, D. 1995. When the Wind Was a River: Aleut Evacuation in World War II. Seattle: University of Washington Press.

Kuzmin, Y. V., G. S. Burr, and A. J. T. Jull. 2001. Radiocarbon reservoir correction ages in the Peter the Great Gulf, Sea of Japan, and eastern coast of the Kunashir, southern Kuriles (northwestern Pacific). Radiocarbon 43:477-481.

Lantis, M. 1970. The Aleut social system, 1750 to 1810, from early historical sources. In Ethnohistory in Southwestern Alaska and the Southern Yukon, Margaret Lantis, ed. Lexington: University Press of Kentucky, 139-295.

Liapunova, R. G. 1996. Essays on the Ethnography of the Aleuts, J. Shelest, trans. Rasmuson Library Historical Translation Series, v. 9. Fairbanks: University of Alaska Press.

Pinart, A. 1873. Voyage la côte nord-ouest d'Amérique d'Ounalashka à Kadiak (îles Aléoutiennes et péninsule d'Alaska). Bull. Soc. Geogr., ser. 6, 6:561-580.

Pinart, A. 1875. La caverne d'Aknanh, île d'Ounga (Archipel Shumagin, Alaska). Paris: E. Leroux.

Sekora, P. 1973. Aleutian Islands National Wildlife Refuge Wilderness Study Report. Washington, DC: U.S. Department of the Interior.

Southon, J. R., D. E. Nelson, and J. S. Vogel. 1990. A record of past ocean-atmosphere radiocarbon differences from the northeast Pacific. Paleoceanography 5:197-206.

Springer, A. M. 1999. Summary, conclusions, and recommendations. In The Bering Sea: Physical, Chemical, and Biological Dynamics, T. R. Loughlin and K. Otani, eds. Fairbanks: Alaska Sea Grant Press, 777-799.

Stuiver, M., G. W. Pearson, and T. F. Brazuinas. 1986. Radiocarbon calibration of marine samples back to 9000 cal BP. Radiocarbon 28:980-1021.

Tikhmenev, P. A. 1978. A History of the Russian-American Company, R. A. Pierce and A. S. Donnelly, eds., trans. Seattle: University of Washington Press.

Trites, A., P. Livingston, S. Machinson et al. 1999. Ecosystem Change and Decline of Marine Mammals in the Eastern Bering Sea: Testing the Ecosystem Shift and Commercial Whaling Hypothesis. Fisheries Research Center Reports, v. 7, pt. 1. Vancouver, Canada: University of British Columbia.

Veniaminov, I. 1984 [1840]. Notes on the Islands of the Unalashka District, L. T. Black and R. H. Geoghegan, trans. Kingston, Canada: Limestone Press. 


\section{Guest Editors}

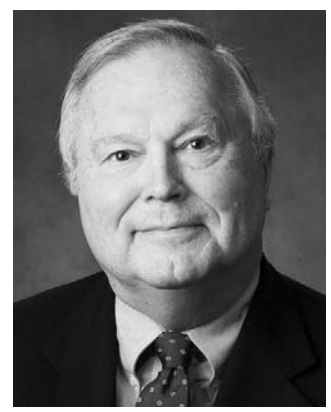

MICHAEL H. CRAWFORD is Professor of Anthropology and Genetics at the University of Kansas, Lawrence. He serves as the director of the Laboratory of Biological Anthropology and the International Consortium for the Study of Tuberculosis. He is a fellow of the American Association for the Advancement of Science and former president and founding member of the American Association of Anthropological Genetics and former president of the Human Biology Association. He served from 1998 to 2000 as editor-in-chief of Human Biology. He has published more than 300 journal articles and book chapters on human biology and anthropological and molecular genetics. In addition, he has either edited or written 16 books and special issues of journals.

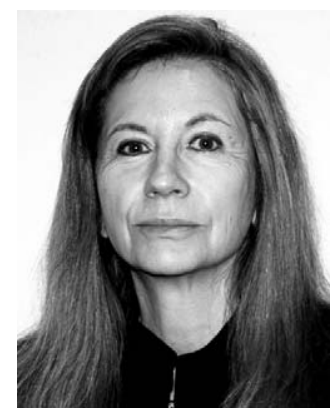

DIXIE L. WEST is a research affiliate with the University of Kansas Natural History Museum and Biodiversity Institute. Her research interests include archaeozoology and Arctic adaptations. With funding from the Office of Polar Programs (National Science Foundation) Dr. West codirected (1997-2003) an international team of researchers to explore prehistoric Aleut interactions with the subarctic environment. From 2005 to 2008, she initiated a new phase of the National Science Foundation's Arctic Research Program. This project and its international, interdisciplinary research team address coupled natural and human systems in the central Aleutian Islands.

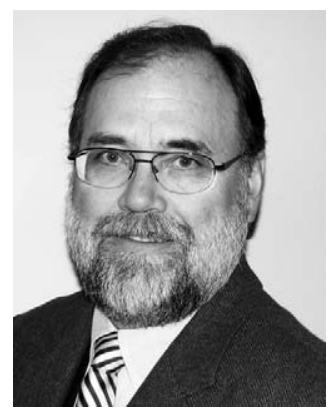

DENNIS H. O'ROURKE is Professor of Anthropology and Director of the Ancient DNA Laboratory at the University of Utah. His research interests include human population genetics, the use of molecular genetic methods to reconstruct regional population histories, American colonization models, and bioethical issues in anthropology and genetics. His research currently is focused in the circumarctic, with a particular focus on North America. He has also conducted aDNA studies in the U.S. Great Basin and the greater Southwest. $\mathrm{He}$ is a former editor-in-chief of Human Biology, past program director for physical anthropology at the National Science Foundation, and the current president of the American Association of Physical Anthropologists. 